\title{
The impact of coping strategies on parental death among young people
}

\section{Zulian Fikry}

Universitas Negeri Padang, Padang, Indonesia.凹zulianfikry.ma@gmail.com

\begin{abstract}
Parental death has a diverse impact on children. Losing is a situation that brings challenges to person who had left behind. The death of parents obscures the figure of a parent who has an important meaning for the development of a child. The result of the loss of a parent figure in the family can cause a variety of negative impacts on the child who is left behind. This qualitative research aims to investigate the ability of stress coping strategies in dealing with the death of parents. Parental death causes a severe psychological burden because the source of love and guidance causes feelings of loneliness, despair, and fear. The feeling of stress has a negative impact on mental health if it is not overcome by a stress coping strategy. This research data was collected using in-depth interviews with teenager who lost their parents in the city of Yogyakarta Indonesia. The results of this study found that death did trigger stress that had never been felt before is the emergence of a deep sadness, anxiety about the fate of self and family in the future, changes in individual attitudes and characters, the emergence of insights about the process of maturity, trying to limit themselves from the relationship, feeling of being unable to economically supported, and a great longing for the figure of parents who died.
\end{abstract}

Keywords:parental death, stress, coping strategies

\section{Introduction}

Parents are the closest figure in a child's life. Between parents and children there is a relationship of love that has been formed since the child was born. Parents will try to give attention to children. According to Santrock (2011) when having children, parents will try to pay attention to their children and also try to keep their partners feeling cared for. This means, as parents, someone will always try to balance his role in the family, both as a couple or as a parent so that a harmonious relationship can be created between the couple and their children.

Children are family members who still cannot afford to take care of themselves before they reach adulthood. Fathers and mothers in the family have their respective roles in children's development. Parents have their own ways to protect and raise their children during development (Bjorklund et al in Cavanaugh, 2006). The role of parents will continue to exist during the child's development process, until he is able to live independently. 
The family is a system, where parents still have an influence on their children. These influences can be either direct or indirect influences (Cavanaugh, 2006). Direct influence can be in the form of both parents acting as an encouragement to children to learn while indirect effects namely by the way parents directly provide examples of behaviors that can be imitated by children such as doing good to others. In addition, the family is also part of the community system. Social environments such as extended families, peers, teachers in schools, are also institutions that influence children's development (Brenfenbrenner in Cavanaugh, 2006). This means parents also play an important role in teaching social skills before children enter the wider social environment in society.

The old paradigm of "full power of parents" (Cavanaugh, 2006) is currently still used mainly in some young families but in fact the relationship between parents and children is mutually influential in family life. Parents and children influence each other through attitudes, actions, and interests shown in their daily interactions.

The existence of the figure of the two parents has an important meaning for the development of children, so that the loss of the parent figure in the family can cause a variety of negative impacts on the children left behind (Stroebe \& Hanson, 1993). According to Carr (2004) the loss of parents can be caused by divorce and death. Some disadvantaged children must accept the harsh reality because their parents died when they were unable to live independently. The death of parents is a very large loss of influence on individuals (Santrock, 2011). The death of a parent can cause a heavy psychological burden on the child because of the loss of a person who is a source of love for the child. This is in accordance with Atwater (1999) who said that the death of a loved one causes loneliness, despair, and fear. This feeling can arise in children and has a negative impact on mental health.

The impact of losing parents can be different for each individual. One of the common effects felt by children is the emergence of stress (Turner\& Helms, 1995). According tothat, it is known that there is a positive relationship between stressors with feelings of sadness due to the death of parents (Kitamura, Sugawara, Toda, \& Shima, 1998). The results of stressors due to the deaths of parentbegan to occur in the period before the parents died. These stressors can adversely affect the various spheres of life of children (Raveis, Siegel, \& Karus, 1998).

After a parent dies, children begins to face a different life situation. Changes that occur in a child's life after the death of a parent are stressors that can affect a child's mental health (Aldwin, 2007). Stressors namely economic inability, relocation, contact lossto friends and neighbors, increased responsibility, loss of longing with alive parent, and livingwith other people (Wolchik, 2006). The stressors that appear can vary according to the condition of the family and children left behind (Moss, 1984).

\section{Method}

The phenomenology approach is used in this study to determine the subject's view of an event or phenomenon that he experiences based on his perspective, therefore the combination of the two approaches is used by researchers to uncover individual coping strategies in dealing with the death of parents. This study aimed to know the individual coping strategies facing the death of parents. Subjects taken in this study refer to certain criteria, among others are:1. An individual whose parents have died; 2 . The subject's parents do not die when giving birth or when the subject is still a baby; 3 . Subject who is unable to live independently and sustain his own life after parents died.

In this study, researchers used interview to gather information. Before conducting the interview, the researcher made a general guide consists of several themes to be answered by interviewee. The themes and questions that will be asked to the subject can still develop during the interview process later during the interview. This method aims to acquiring in-depth information of thinking, feelings, and subjective experience a person perceived throughout an event. The next step of data collection technique used in this study was observation during the interview. The purpose of the observation is 
to describe the settings learned, the activities that take place, the people involved in the activity, and the meaning of the events seen from the perspective of those involved in the observed events. Subject for this study are a pair of individuals, a male aged 26 years old and a female aged 25 years old.

\section{Results and Discussion}

a. Male subject

Thoughts

Before parent death a person had their own perceptions of their experience. The male subject perceive overwhelmed feeling of responsibility to the parent sickness. The male experienced several situation that demanded his role as oldest brother in his family. As what happened in the fourth day his dad in hospital care, his father condition was not improve but got worse. Doctor decided to use respiratory supporting equipment and demand patient to be relocated to private hospital with ICU unit. Subject had preassume his father were got better after he had relocated for a while, but at midnight his condition just got critical.

"Siang harinya papa tu masih sadar, terus kata dokternya karena papa susah napas harus dipasang ventilator namanya, tapi harus ditidurkan dulu, dibius total lah waktu itu. Terus malamnya udah tenang, apalagi udah pindah rumah sakit ke RS swasta yang lebih bagus.

Terus,waktu itu mendadak aja datang panggilan dari dalam keluarga di suruh masuk. Padahal waktu itu, saya baru aja keluar dari ruangan itu, langsung masuk lagi karena dipanggil itu kan. Keliatanlah dokter sedang nekan-nekan dada papa, papa ni udah diam aja, matanya kebuka dikit, mama udah nangis-nangis waktu itu."

Subject's father passed away with his wife and son had witnessing. Subject told the situation at that time made his mind like stopping suddenly. His younger brother who arrived few minutes after the dad passed away was shocked and as subject said look up set and filled with anger.

"saya lihat adek saya yang kecil baru datang, saya peluk dia tapi dia malah seperti marah kesal gitu,.bilangnya "hhh,, issh," kayak orang kesal gitu. Waktu itu dia memang masih kelas tiga SMP dan pasti dia kaget sekali lebih daripada saya."

Findings related to stressful condition prior to parent death according to male subject involved feeling of unreadiness, thought the death come extremely sudden, beyond of what he can anticpated, made him felt deep shock, unable to handle the truth, and feeling like he was dreaming but he was completely awake.

"Benar-benar kaget, kayak mimpi aja waktu itu. Parah, seperti percaya gak percaya gitulah, waktu itu saya betul-betul gak menyangka dan gak yakin kalau papa itu udah meninggal itu."

Other stress-related thoughts appeared was the prejudice that the doctor was completely wrong to declare his dad's death. Along with this feeling he also felt severe fatique and unrealistic thoughts about future before him.

"Rasanya saya itu letih saja. Saya bingung saja, ini mimpi atau salah diagnose, atau apa. Janganjangan salah diagnosa, dan saya berharap dokter didalam ruangan itu memeriksa papa lagi dan papa gak jadi meninggal. Saya mikir apa yang akan terjadi nanti dalam hidup saya, banyak bercampur aduk, karena saya baru pertama kali mengalami kematian orang tua."

Other stress-related thoughts appeared was the prejudice that the doctor was completely wrong to declare his dad's death. Along with this feeling he also felt severe fatique and unrealistic thoughts about future before him.

"Saat itu saya sempat merasa hidup saya nanti akan sulit dengan keadaan ini. Apalagi keluarga kami hanya sedikit, hanya berlima, sekarang tinggal empat. Tapi semua itu tidak ingin saya perlihatkan kepada mama dan 
adik-adik saya. Saya berusaha selalu menguatkan mereka dengan selalu mengingatkan untuk selalu mendoakan papa."

He wanted his father to wake up again and he felt he desperately needed his father. He did not expect his father to die at that time. After his father died he thought in uncertain direction. He felt confused and that time he also hoped his father would live again. He had questioned fate and asking whyhis father had gone so soon. However, in his mind also reminded him not to drag on sadness. At that time he was aware of it but did not know the right way to get rid of sadness.

Feelings

When he found out his parents had died, he felt like he was not in where he was, like he is in other dimension, His was felt strange, erratic, and his body felt like afloating, but at that moment he couldn't cry even though he wanted to do it. He could not cry and felt like a dream, he also felt that his father was just pretending to be dead. According to him this feeling arises because he feels sad and does not accept the death.

"saat itu saya merasa kejadian itu seperti mimpi saja, sepertinya papa itu hanya pura-pura mati. Itulah yang saya rasakan saat itu, saya merasa sedih, tapi juga tidak terima."

On the day of his father's funeral, the subject tried to restrain himself so that his sadness would not be seen by his mother and younger siblings. According to him he felt very sadness but he tried to concern himself with his father's funeral procession. At night after the burial finally he cried alone in silence. He felt relieved and released after crying.

How he dealt with his feeling become the key of stress relief. He began to take several steps to get rid the sadness. Some of the steps like bought a new cell phone which he had never own before. Another way, he bought a large amount of cigarettes, since he is already a smoker, an smoked as much as he could in his house, a behavior that had never been done before since his father banned smoking at home for his children.

"Saya membeli handphone android untuk online, saya beli rokok satu slof untuk teman saya empat hari sendirian di rumah. Selama ini saya merokok sembunyi-sembunyi, saya tidak pernah merokok di depan orang tua, tapi waktu itu saya beli banyak dan saya puaskan merokok di rumah. Saya merokok hampir gak berentiberenti."

According to his testimony he really enjoyed his own time at home at that time, and he felt he had managed to free himself from the pressure he felt because of his sadness.

"Saya nikmati waktu-waktu sendirian di rumah itu, saya browsing internet, saya nonton film, main game sepuasnya, saya lepaskan diri saya saat itu"

the behavior he did was done for three days when his mother was abroad. The impact he felt at that time was that he felt he was the oldest man at home and who had to be able to lead the family.

"Saat itu saya merasa sayalah lelaki di rumah saat ini, gak ada yang bisa menghalangi saya, sayalah orang yang harus mampu menggantikan papa memimpin keluarga."

In addition, he felt very satisfied, happy, and focused on refocusing his mind. He claimed to have begun to forget the sadness since the incident.

"Jujur saja saya merasa puas, bahkan sampai muak menyenangkan hati saya, saya udah merasa benar-benar senang, dan saya udah ga pengen lagi senang-senang. Waktu itu pikiran saya udah bisa fokus, perlahan kesedihan saya mulai saya coba lupakan dan saya fokus untuk ke depan menjaga mama dan adik-adik."

"Saya merasa kembali hidup normal setelah tekanan itu saya lepaskan dari batin dan pikiran saya"

After feeling himself released from the pressure, the stress declined, and he felt his life returning to normal. 
"Besides that the release of pressure and stress that was felt made SLK again optimistic, especially towards the family economy.

"iya, tapi intinya kami waktu itu sudah kembali optimis dalam menjalani kehidupan. Kalau saya, terutama dalam ekonomi, karena saya orang yang materialis.Saya takut awalnya kalau-kalau keuangan kami terancam, karena adek-adek masih butuh biaya. Saya sendiri waktu itu kerja dan gaji saya lumayan bisa ditabunglah. Tapi Alhmadulillah kekhawatiran saya tidak terbukti."

The family also has joint activities to release stress and entertain themselves by travelling to some pleace every week out of town together doing fun activities.

According to male subject, the most valuable lesson he got from his father's death was learning to give up, be sincere, death must come we like it or not, always pray, loving our parents and family as best we could when they were still alive.

His parents when he had entered early adult age. At this time thought which is characterized by the ability to think logically and practically (Santrock, 2011). His father's death shocked him greatly, because at the time before the death, he felt his father had gone through a critical stage and had been handled by doctors and hospitals of good quality. So that when he found out his parents died he was in a state of being unprepared. When his father died included: feeling sad, shocked, distrustful, feeling like he was dreaming, unable to think anything, feeling he was not where he was at that time, feeling a strange feeling without cause, and his body feels like floating. The sensory experience of feeling floating is a unique experience experienced by the subjects of this study, where only his claimed to feel it. When faced with the death of his parents he could not cry, his mind became chaotic, and hoped that he would come back to life.

He tried to cover up his sadness from his family, besides that he also tried to strengthen his mother and family in this situation, even though he actually felt very sad. The action of SLK who tried to hide his sadness done by using an emotion-focused coping strategy, aimed to control the turbulent emotions inside him at that time in order to still look calm in front of his family. He tried to ease the burden of his mind by sharing stories with his best friend, but he considered that method was unsuccessful because it only reduced sadness and did not overcome the source of the sadness he felt. Telling the problem to others to relieve emotions is also a form of emotional-centered coping strategy, called the strategy Seeking social support (seeking social support), which is an effort to seek support from outside parties, both in the form of information, real assistance and emotional support in an effort adjust the feelings and actions taken (Lazarus \& Folkman, 1984).In order to eliminate the source of sadness, he tried to do several ways. The first way is to let go of emotional control at a time and place that he considers conducive, namely when alone at night, so that he can cry to his sadness all the way after that he felt relieved. Crying is a form of emotionally centered strategy.

According to Lazarus \& Folkman (1984) a form of coping strategy like subject done with had a lots of fun things that have never been done, such as he smokes as much as he likes, buys the latest model phones, and does fun activities for himself, such as playing with cellphones, watching movies is called distancing, which describes the reaction to break away or try not to get involved in the problem. When he was distorted from the stress of the death of his father, he released himself from sadness doing whatever he liked to feel very satisfied and even fed up with such fun activities. After releasing his tension he felt he no longer wanted to do anything, he could focus on thinking about the fate of himself, his mother and younger siblings in the future, and according to him he felt his life was normal again, a fun activity he did aims to release negative feelings by doing as many positive things as possible. Distancing the form of strategy when examined it turns out to be in tandem with the emergence of a form of coping Accepting responsibility, efforts to acknowledge his feelings in the problems faced and make the he finally able to put everything properly as it should be especially related to his family. 
Besides the coping strategies that are carried out individually by the subjects, there are also coping strategies that are carried out jointly by family members. Families do fun activities together by traveling out of town every week. The benefits of these activities, the family can let go of negative feelings and can live life as usual. One of the effects of the death of parents for his family is increasing familiarity of the nuclear family with large family members such as grandfather and aunt, so that the family sphere extends to the increase in its members.

b. Female subject

Thoughts

Female subject lost his dad in age fifteen years old. Her father had suffer for heart attack and led him into coma. During his father was hospitalized, herself and her family always be able to accompany the patient. Along with the sadness she also felt unable to help and so pity to see his father's suffering in coma. She cried every day at the hospital seeing his father's condition and still not accepting the situation. father had previously had stable health condition made the family cannot believe the father had suddenly got very ill.

"Selama ini papa sehat-sehat aja, dan belakangan memang ceria sekali. Habis itu, dua hari setelahnya dapat kabar papa pingsan gitu, "nah,..tiba-tiba kenapa ini. Kok bisa gitu ya,..?" gitu aja ekspresi yang bisa.

"Selama enam hari papa di rumah sakit itu, selama itu saya merasa dunia ini aneh rasanya, dari yang senang-senang tiba-tiba langsung berubah jadi kayak gitu. Jadi saya tu cuma bisa "hahh..!?" cuma bisa ngerasa gitu, terpana, shock, kayak gitu. Masih berusaha menyadari kok bisa gitu, kayak gitulah yang saya rasakan hari itu."

Subject got confused of how could their father got into coma and she had no clue to find the way to help him. She got shocked and stranded in feeling limbo while keep wondering what is going on without knowing what to do.

Her mother realizedthe condition worsening, she asked her and her younger siblings to prepare themselves for the worst. At the time she could only obey and not do much because she was also in confusion and had given up of anything that would happen to his father.

“...biarlah daripada papa kayak gitu,koma gitu kan, gak tahan, saya benar-benar gak tahan ngelihat orang koma."

After the death, subject felt her personal life changed dramatically. She felt his life was not the same as when he still had a father. She had lost the comfort zone of his life, when he suddenly lost his father. When she entered high school father lost increased feeling of emptiness and forced her as the eldest sister in family, to ease the burden of the mother and set a good example for her younger siblings, which she decided to provide financial support by her own.

"Setelah papa meninggal itu autopilot saya itu gini, saya anak pertama, cuma punya mama, jadi saya intinya autopilot itu gak mau menyusahkan mama. Karena saya merasa gitu, saya jadi yang biasanya minta ini minta itu langsung aja, sekarang itu jadi mikir nanti takut nyusahin mama gitu"

Her family system also expanded with more intense relationship to their relatives. Herself andher siblings were very close to Grandma, uncle and aunt. After the death of his father, these people played a role in helping the life of the SPR family.

She believe she had learned a lot after losing his father. The death of his father taught him to be mature. She became motivated to start learning to be mature. At that time he considered that adults meant not to bother others, understand the situation of others and know the situation.

The death had changed her to be someone who was more able to accept the situation and reality that happened. See learn to be more able to control emotions and become more aware of God's 
power. She make his father's character as a role model, she learned from memory of her father how to control himself, tips on communicating, and how to get along well with friends.

“...banyak pelajaran yang didapat dari kepergian papa. Sekarang saya tau yang jadi dewasa itu seperti apa, walaupun masih belum sepenuhnya, tapi saya merasa dulu saya begitu dan melalui proses untuk menjadi lebih dewasa gitu kan."

"Pokoknya gini, pas kematian papa saya banyak mensyukuri beberapa hal gitu loh,..Saya mensyukuri dulu itu saya orangnya yang suka gak terima apa yang gak disuka gitu."

"Banyak hal-hal yang juga saya syukuri, misalnya dulu saya itu egois, meledak-ledak, terus yang ketika papa meninggal itu berubah. Pas papa meninggal itu saya merasa "oh, iya di dunia ini tuhan bisa melakukan apa aja".

"...sehabis kematian papa itu, momen kematian papa itu membuat saya lebih dekat sama tuhan,..."

For her, father death considered as her heaviest life burden so she perceived other life burdens as lighter and insignificant compared to father lost. This thought helps her to survive and to be resilient through time after the death. She also realized that her mother and siblings is what she had and she have to take a good care of them more than before. She decided to apply more responsibility to family's financial spending, for example by only bought stuff she really need most and avoid unnecessary purchases.

Feelings

Father's death left heavy burden on her feelings because the sadness stays for quite long time.She once felt empty for a week after her father died. But she did not tell anyone about her feelings.

Another stress related feeling happened due to her status turned into an orphan. That time she did not want to be considered as an orphan. shee felt she did not need any help from anyone who consider her orphanage. Her mind refused if she was considered an orphan because he believed he could survive without those kind of assistances.

"dulu waktu awal-awal papa meninggal itu, kan ada sumbangan untuk anak yatim gitu kan untuk kami. Saya sama adik saya yang nomer dua itu gak pernah mau terima. Kami pikir waktu itu, "kok sekarang giliran saya sih, saya gak mau kayak gini". Itulah penolakan (batin) yang pertama saya rasakan. "kami gak butuh itu kok, kami mampu kok walaupun papa udah gak ada." Terus perubahan yang kayak gitu, yang berhubungan sama anak yatim gitu-gitu. Saya masih belum nerima yang kayak gitu, sampai waktu SMA."

She still feels missing for his father the whole time after her age 25 years old.Subject sometimes had to hold herself and decided to not join friend's party or do not go hang out with friends because she did not have enough money. Sherealized that at the time she often harbored the stress she felt himself, she did not want to talk about his feelings openly.

"Saya entah kenapa belajar sendiri aja, tapi ya itu, imbasnya itu saya kadang jadi stres sendiri, terbebani sendiri gitu".

Even though in she harbored all problems on her own, She still displayed the cheerful side of her at school. But at that time she set clear boundaries for her privacy with her friends so that the burden she felt was hidden to others.

"Saya kalau stres saya pendam aja sendiri, dak ngomong sama orang. Waktu SMA saya gak mau bicarakan masalah saya ke orang lain, bukan berarti saya orangnya gak heboh, saya orangnya suka bercanda kok, tapi my privasi ya my privasi gitu, saya bisa memilah-milah itu. Mungkin teman-teman liat saya senang, tapi dalamnya saya stres."

She dealt with stress and sadness by doing fun activities with friends, namely activities that can make her laugh and feel happy. The activities that she usually does at that time are having fun with 
friends, taking a walk, playing music, or telling stories about music with friends. She tried to forget the things that made her mind and feelings filled with joy.

"Saya atasi sendiri aja, dulu tu saya suka mencari kesenangan sendiri gitu. Saya punya kawan-kawan yang suka membawa saya senang-senang, misalnya jalan-jalan. Saya jadi suka musik itu karena kawan-kawan, saya punya teman yang enak dibawa cerita soal musik, jadi masalah-masalah yang saya rasakan itu jadi terlupa gitu, "bodo amat" gitu. Intinya saya menjalani apa adanya dan menerima yang diberikan sama mama,..."

The coping strategies carried out by the female subject regarding parent's death include the distancing form (Lazarus \& Folkman, 1984). The absence of a father instinctively push he to try to be independent and strengthen himself to ease the burden of the mother and set a good example for her younger siblings. She tried to hold back unnecessary expense to save family's finances. It help to ease the burden of mothers with frugality. Sometimes shecaught at a dilemma when she wanted to buy something for herself if that could led to more burden to the mother. She also reminded her younger siblings to try to help ease the burden of the mother by frugality, so that the frugal lifestyle became a habit for the family at the time.

Some of these ways are planful problem solving as a form of coping that focuses on problems (Lazarus \& Folkman, 1984). The psychological burden made her feel stressed, filled with sadness and turned into a quiet person. At the time he often harbored the stress she felt himself, did not want to talk about her feelings openly. Coping strategies by harboring feelings like this in silence are called self-control strategies, namely efforts to regulate one's own feelings and actions to be carried out. She harbor her problems inside while still displaying cheerful side at school and others. At that time of losingshe set clear boundaries for her privacy with friends so that the burden she felt was unknown to others.She overcomes the sadness not by overcoming the source of the problem, but by covering it up by seeking pleasure. This shows another form of coping strategy used in overcoming the pressure he faces, namely escape-avoidance, which describes the reaction and attempts to avoid or escape the problem at hand.

\section{Conclusions}

This study found that the death of parents among young people is a stressful situation. The stress that occurs is caused bydeep sadness, anxiety over the survival of self and family, the feeling of being unable to accept the reality that happened, forcing themselves not to look sad, losing support from people who are trusted, and decreasing economic capacity. The results also showed differences in the stressful effects of parental deaths on both subjects. The response given to stressors in male subjects is indicated by the inability to express sadness when death occurs, then sadness can be released after the subject has remained silent and alone. After releasing the pressure the male subject is looking for activities that give a feeling of being free and happy, until finally he no longer feels sadness because he is so satisfied doing what he wants without any restrictions. Then after that it didn't take long for him to regain control of himself to fulfill his responsibilities after father's death.

Whereas in women the response to stress has been seen since the treatment period before parents die. the subject has felt psychological pressure since the time the patient has a coma. Then after the patient dies, the female subject feels that she and her family have given up their death as the best for their father. However, in reality sadness is felt to last for years after death. The impact of sadness that persists in the subject is the change of character in social life, self-closing, feeling economically inadequate, and a great sense of longing for the figure of a deceased parent.

The experience experienced by the loss of parents in the subject of this study, also shows the emergence of a positive impact on the subject. Loss makes subjects more independent, more responsible, and sensitive to the future conditions of the family. Father's death encourages the subject to choose to see life more mature and rational. Subjects learn from bad experiences to be more steadfast and dare to face life's challenges by relying on their own abilities. 


\section{References}

Aldwin, C. M. (2007). Stress, coping, and development: An Integrative Perspective. (2 nd ed). New York: Guilford Press.

Atwater, E. \& Duffy. K. G. (1999). Psychology for living: Adjusment, growth,and behavior today. (6 ${ }^{\text {th }}$ ed). New Jersey: Prentice Hall, Inc.

Kitamura, T., Sugawara, M. Toda, M. A. \& Shima, S. (1998). Chilhood adversities and depression: I. Effect of early parental loss on the rearing behavior of the remaining parent. Archieve of Women's Mental Health. (1). 131-136.

Lazarus, R. S., Folkman, S. (1984). Stress, appraisal, and coping. USA: Springer publishing company.

Moss, M. (1984). The impact of parental death on middle aged children. Omega, 14(1), 65-75.

Raveis, V. H., Siegel, K., \& Karus, D. (1998). Children's psychological distress following the death of a parent. Journal of youth and adolescence, 28(2), 165-180.

Santrock, J. W. (2011).Life span development. (13 th ed). New York: McGraw-Hill Companies, Inc.

Stroebe, M. S., \& Hanson, R. O. (1993). Handbook of bereavement: Theory, research, and intervention. USA: Cambridge University Press.

Turner, T. S., \& Helms, D. B. (1995). Lifespan Development. (5 ${ }^{\text {th }}$ ed). USA: Harcourt Brace College Publisher

Wolchik, S. A., Tein, J. Y., Irwin, N. S. \& Ayers, T. S. (2006). Stressors, quality of the child caregiver relationship, and children's mental health problem after parental death: The mediating role of self system beliefs. Journal of abnormal child psychology, 34(2), 221- 238. 